\title{
Aggregate Presentation of the Financial-Banking System in Romania and France
}

\author{
Viorica Ioan ${ }^{\star}$, Ioana Lazarescu ${ }^{\star \star}$, Cristina Garstea ${ }^{\star \star \star}$
}

\begin{tabular}{l}
\hline \multicolumn{1}{c}{ A R T I C L E I N F O } \\
\hline Article history: \\
Accepted November 2020 \\
Available online December 2020 \\
\hline JEL Classification \\
E50, G21 \\
Keywords: \\
Financial-banking, Monetary \\
institutions, Consolidated balance \\
sheet, Internal and external assets, \\
Credit, Risk, Portfolio
\end{tabular}

\begin{abstract}
A B S T R A C T
Banking activity is necessary and fundamental in the socio-economic operation by involving economic flows and circuits, present in correlation with the financial element. From this perspective, the banking activity is characterized by the complexity and diversity of risks, an ascending evolution due to the increase of the economic-financial circuits on the domestic and international banking financial markets. Moreover, the burden on the financial sector highlights how economic growth and financial stability evolve in line with risk management in the banking system. Therefore, banks in the Romanian and French banking system operate according to a program developed to identify, quantify, know, and initiate measures to avoid or reduce risks.
\end{abstract}

(c) 2020 EAI. All rights reserved.

\section{Introduction}

The aggregate level of financial-banking stability in Romania and France has an intrinsic role, characterized by the monetary and prudential authority at the internal and external level. The efficiency of the existing banking system and financial markets is one of the determining factors for the sustainable growth of the domestic investment portfolio. As in 2019, the Banque de France mentioned the need for a transformation of the economic system and the financial sector based on "green financing", a new model of macroeconomic development. Therefore, the Romanian system is highlighted by a tendency to focus on investments within the country, and the French system is concentrated not only internally but also externally by attracting new markets. In order to record these values, the financial system, consisting of savings and investment intermediaries, has the capacity to deal with financial shocks and possible corrections of financial imbalances.

\section{Net consolidated balance sheet dynamics of monetary financial institutions in Romania}

Therefore, before understanding the specificity of each bank, it is necessary to understand the framework and economic situation of financial-banking institutions. Once analyzed, the Romanian and French banking sectors' structural differences are perceived, respectively, the divergences in the capital structure and risks between BRD and SG. Table 1 presents the Net Consolidated Balance Sheet dynamics of the monetary financial institutions (MFIs) in Romania for the period 2015-2019. As can be seen, the Romanian banking sector during the years 2015-2019 increased on average by 6\% annually, from 493.3 billion lei in December 2015 to 622.8 billion lei in December 2019. The contribution to the total assets of investments between external support and internal assets are practically identical, external assets having on average $38.5 \%$, and internal assets having $61.5 \%$, which demonstrates the Romanian banking sector's tendency to concentrate its investments within the country. Likewise, the dynamics of increasing the ratio of internal liabilities to the total liabilities of MFIs in Romania is observed, registering values from 84.65\% in December 2015 to $91.28 \%$ in December 2019. 
Table 1. Net Consolidated Balance Sheet dynamics of the monetary financial institutions in Romania

\begin{tabular}{|c|c|c|c|c|c|c|}
\hline Indicators & U.M. & 2015 & 2016 & 2017 & 2018 & 2019 \\
\hline $\begin{array}{l}\text { Total } \\
\text { ASSETS }\end{array}$ & $\begin{array}{l}\text { (thousand } \\
\text { lei) }\end{array}$ & 493.903.386,2 & $527.802 .509,2$ & $553.430 .604,3$ & $583.695 .063,3$ & $622.814 .401,5$ \\
\hline $\begin{array}{l}\text { External } \\
\text { Assets }\end{array}$ & $\begin{array}{l}\text { (thousand } \\
\text { lei) }\end{array}$ & $186.124 .444,1$ & $211.572 .407,8$ & $220.299 .019,4$ & $224.360 .843,9$ & $236.180 .907,5$ \\
\hline $\begin{array}{l}\text { Internal } \\
\text { Assets }\end{array}$ & $\begin{array}{l}\text { (thousand } \\
\text { lei) }\end{array}$ & $307.778 .942,1$ & $316.230 .101,5$ & $333.131 .584,9$ & $359.334 .219,4$ & $386.633 .494,1$ \\
\hline $\begin{array}{l}\text { Total } \\
\text { LIABILITIES }\end{array}$ & $\begin{array}{l}\text { (thousand } \\
\text { lei) }\end{array}$ & $493.903 .375,0$ & $527.802 .508,2$ & $553.430 .676,6$ & $583.695 .137,4$ & $622.814 .478,6$ \\
\hline $\begin{array}{l}\text { External } \\
\text { liabilities }\end{array}$ & $\begin{array}{l}\text { (thousand } \\
\text { lei) }\end{array}$ & $75.824 .563,8$ & $66.589 .230,1$ & $61.310 .318,7$ & $57.783 .218,9$ & $54.333 .482,2$ \\
\hline $\begin{array}{l}\text { Internal } \\
\text { liabilities }\end{array}$ & $\begin{array}{l}\text { (thousand } \\
\text { lei) }\end{array}$ & 418.078.811,2 & $461.213 .278,1$ & 492.120.357,9 & $525.911 .918,4$ & $568.480 .996,4$ \\
\hline $\begin{array}{l}\text { External } \\
\text { liabilities }\end{array}$ & $(\%)$ & $37,68 \%$ & $40,09 \%$ & $39,81 \%$ & $38,44 \%$ & $37,92 \%$ \\
\hline $\begin{array}{l}\text { Internal } \\
\text { liabilities }\end{array}$ & $(\%)$ & $62,32 \%$ & $59,91 \%$ & $60,19 \%$ & $61,56 \%$ & $62,08 \%$ \\
\hline $\begin{array}{l}\text { External } \\
\text { liabilities }\end{array}$ & $(\%)$ & $15,35 \%$ & $12,62 \%$ & $11,08 \%$ & $9,90 \%$ & $8,72 \%$ \\
\hline $\begin{array}{l}\text { Internal } \\
\text { liabilities }\end{array}$ & $(\%)$ & $84,65 \%$ & $87,38 \%$ & $88,92 \%$ & $90,10 \%$ & $91,28 \%$ \\
\hline $\begin{array}{l}\text { Growth } \\
\text { Total assets } \\
\text { / liabilities }\end{array}$ & $(\%)$ & N/A & $6,9 \%$ & $4,9 \%$ & $5,5 \%$ & $6,7 \%$ \\
\hline
\end{tabular}

Source: Created by author based on data from the consolidated balance sheet net of monetary financial institutions, available at https://bnr.ro/Baza-de-date-interactiva-604.aspx\#, accessed on 14.04.2020

Table 2 presents the value structure of external and internal assets of MFIs in Romania, as well as their dynamics, and Table 3 presents the percentage structure of external and internal assets of MFIs in Romania for the analyzed period. Moreover, the analysis shows that the portfolio of Romanian MFIs is largely focused on investments within the country, namely the lending portfolio which constitutes $71 \%-74 \%$ of total domestic assets, where there is a growing difference of 51.2 billion lei for December 2019.

Table 2. Net consolidated balance sheet dynamics of monetary financial institutions in Romania

\begin{tabular}{|c|c|c|c|c|c|c|}
\hline Indicators & U.M. & Dec. 2015 & Dec. 2016 & Dec. 2017 & Dec. 2018 & Dec. 2019 \\
\hline External Assests & $\begin{array}{l}\text { (thousand } \\
\text { lei) }\end{array}$ & 186.124.444,1 & $211.572 .407,8$ & $220.299 .019,4$ & $224,360,843.9$ & $236,180,907.5$ \\
\hline External assets; loans & $\begin{array}{l}\text { (thousand } \\
\text { lei) }\end{array}$ & $33.233 .580,0$ & $60.755 .203,0$ & $79.483 .441,8$ & $80.083 .842,0$ & $65.583 .208,3$ \\
\hline $\begin{array}{l}\text { External assets; } \\
\text { negotiable securities }\end{array}$ & $\begin{array}{l}\text { (thousand } \\
\text { lei) }\end{array}$ & $128.621 .802,3$ & $112.876 .527,9$ & $103.190 .724,4$ & $105.275 .164,2$ & $125.850 .398,2$ \\
\hline $\begin{array}{l}\text { External assets; shares } \\
\text { / units of money } \\
\text { market funds and } \\
\text { investment funds }\end{array}$ & $\begin{array}{l}\text { (thousand } \\
\text { lei) }\end{array}$ & $103.073,3$ & $94.415,7$ & $85.525,7$ & $2.290,1$ & $3.791,3$ \\
\hline $\begin{array}{l}\text { External assets; shares } \\
\text { and other equity }\end{array}$ & $\begin{array}{l}\text { (thousand } \\
\text { lei) }\end{array}$ & $6.774 .618,1$ & $11.188 .964,3$ & $10.870 .989,8$ & $11.045 .788,2$ & $11.634 .478,7$ \\
\hline Internal assets & $\begin{array}{l}\text { (thousand } \\
\text { lei) }\end{array}$ & $307.778 .942,1$ & 316.230.101,5 & $333.131 .584,9$ & $359.334 .219,4$ & $386.633 .494,1$ \\
\hline $\begin{array}{l}\text { Internal assets; } \\
\text { internal loans }\end{array}$ & $\begin{array}{l}\text { (thousand } \\
\text { lei) }\end{array}$ & $226.031 .214,0$ & $230.586 .292,4$ & $241.873 .164,0$ & $260.165 .822,6$ & $277.236 .179,8$ \\
\hline $\begin{array}{l}\text { Internal assets; } \\
\text { negotiable securities }\end{array}$ & $\begin{array}{l}\text { (thousand } \\
\text { lei) }\end{array}$ & $78.737 .696,0$ & $82.819 .876,8$ & $88.841 .153,4$ & $96.466 .605,9$ & $106.592 .455,6$ \\
\hline $\begin{array}{l}\text { Internal assets; shares } \\
\text { and other equity }\end{array}$ & $\begin{array}{l}\text { (thousand } \\
\text { lei) }\end{array}$ & $3.010 .032,1$ & $2.823 .932,3$ & $2.417 .267,5$ & $2.701 .790,9$ & $2.804 .858,7$ \\
\hline
\end{tabular}

Source: Created by author based on data from the consolidated balance sheet net of monetary financial institutions, available at https://bnr.ro/Baza-de-date-interactiva-604.aspx\#, accessed on 14.04.2020

The share of credit securities and credit instruments on the money market of MFIs is approximately $26.5 \%$ of total domestic assets, an increase of 27.9 billion lei for December 2019. For external assets, there is 
also a trend increase in direct lending to external entities (17.86\% in 2015, compared to $27.77 \%$ in 2019) and a decrease in the portfolio of negotiable securities (from $69.11 \%$ in 2015 to $53.29 \%$ in 2019 ).

Table 3. Percentage structure of internal and external assets of MFIs in Romania

\begin{tabular}{|l|r|r|r|r|r|r|}
\hline Indicators & \multicolumn{1}{|c|}{ U.M. } & Dec. 2015 & \multicolumn{1}{|c|}{ Dec. 2016 } & \multicolumn{1}{|l|}{ Dec. 2017 } & Dec. 2018 & Dec. 2019 \\
\hline $\begin{array}{l}\text { External assets; } \\
\text { loans }\end{array}$ & $(\%)$ & $17,86 \%$ & $28,72 \%$ & $36,08 \%$ & $35,69 \%$ & $27,77 \%$ \\
\hline $\begin{array}{l}\text { External assets; } \\
\text { negotiable } \\
\text { securities }\end{array}$ & $(\%)$ & $69,11 \%$ & $53,35 \%$ & $46,84 \%$ & $46,92 \%$ & $53,29 \%$ \\
\hline $\begin{array}{l}\text { Internal assets; } \\
\text { internal loans }\end{array}$ & $(\%)$ & $73,44 \%$ & $72,92 \%$ & $72,61 \%$ & $72,40 \%$ & $71,71 \%$ \\
\hline $\begin{array}{l}\text { Internal assets ; } \\
\text { negotiable } \\
\text { securities }\end{array}$ & $(\%)$ & $25,58 \%$ & $26,19 \%$ & $26,67 \%$ & $26,85 \%$ & $27,57 \%$ \\
\hline
\end{tabular}

Source: Created by author based on data from the consolidated balance sheet net of monetary financial institutions, available at https://bnr.ro/Baza-de-date-interactiva-604.aspx\#, accessed on 14.04.2020

Following the analysis of the data presented in table 1,2 and 3, can be distinguished the following conclusions about MFIs in Romania:

- Romanian banking sector increases on average by $6 \%$ annually;

- Investments in the Romanian banking sector is concentrated within the country, and the contribution of external and internal assets in the structure of consolidated assets is stable at $38.5 \%$ and $61.5 \%$;

- The Romanian banking sector tends to attract financing from within the country, and domestic liabilities in 2019 constitute $91.28 \%$ of the total liabilities of MFIs;

- The internal asset is made up of the loan portfolio comprising between the values $71 \%-74 \%$ and investments in credit securities constitutes $26.5 \%$;

- External assets consist of negotiable debt securities (53\%) and direct loans to external entities constitutes $27.77 \%$.

\section{The evolution of banking activities in France}

Figure 1 examines the evolution of banking in France. Therefore, the French system shows the dynamics of loans granted to euro area residents by MFIs. Following the analysis of the data, it can be seen that in the first quarter of 2016 in France, loans were granted in the total amount of EUR 4.4 trillion, and in 2020 of EUR 5.65 trillion, an increase of $28.4 \%$, respectively of $6.4 \%$ per annum. The annual growth rate oscillates between the minimum value of $3 \%$ in the first quarter of 2017 and the maximum value of $10.3 \%$ in the third quarter of 2018 , with an average arithmetic growth of $7 \%$.

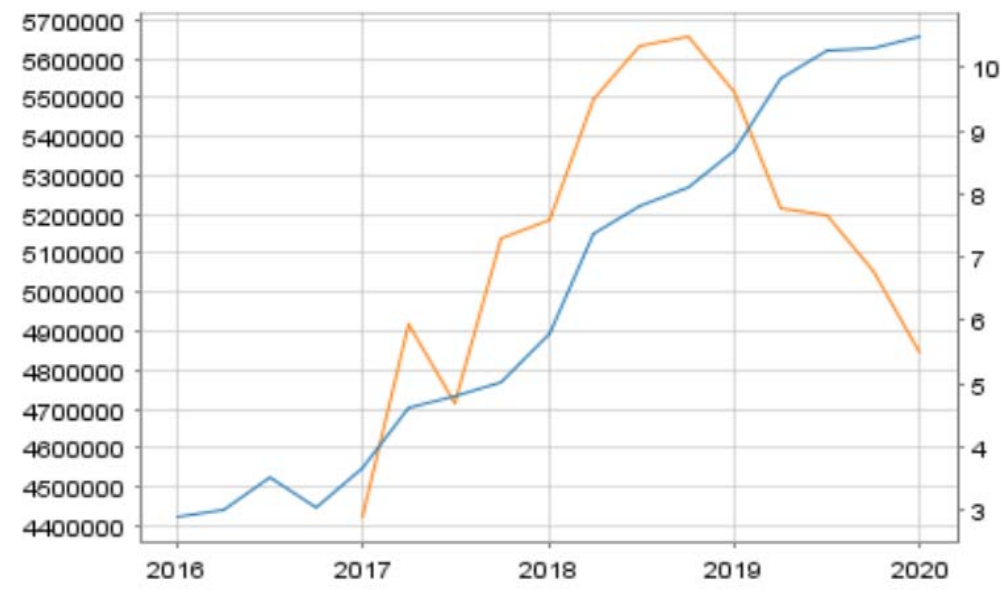

Figure 1. Dynamics of the increase in the total amount of loans granted by French MFIs to euro area residents

Source: Carried out by the author on the basis of data provided by the BCE in the consolidated financial statements, available at http://sdw.ecb.europa.eu/browse.do?node=9691106, accessed on 16.04.2020

Table 4 shows the aggregate balance of French MFIs for the last three years. As can be seen, the structure of the balance sheet assets for French MFIs is as follows: external assets occupy $15.2 \%$ of the total, and domestic assets $84.8 \%$. The balance sheet liability design is practically identical to that of the balance sheet asset from the internal-external perspective. Thus, French banks lend a dominant volume to euro area customers and entities, accounting for $84.8 \%$. 
Table 4. Aggregate balance of MFIs in France for years 2017, 2018, 2019

\begin{tabular}{|l|l|r|r|r|}
\hline Indicatori & U.M. & $\mathbf{2 0 1 7}$ & $\mathbf{2 0 1 8}$ & $\mathbf{2 0 1 9}$ \\
\hline Total ASSETS & (mld. EUR) & $\mathbf{8 . 1 0 1 , 9}$ & $\mathbf{8 . 4 7 7 , 2}$ & $\mathbf{9 . 0 0 1 , 4}$ \\
\hline External assets & (mld. EUR) & $1.015,4$ & $1.231,4$ & 1370 \\
\hline Internal asstes & (mld. EUR) & $7.086,5$ & $7.245,8$ & $7.631,4$ \\
\hline Total LIABILITIES & (mld. EUR) & $\mathbf{8 . 1 0 1 , 9}$ & $\mathbf{8 . 4 7 7 , 2}$ & $\mathbf{9 . 0 0 1 , 4}$ \\
\hline External liabilities & (mld. EUR) & 957,6 & $1.276,1$ & $1.367,3$ \\
\hline Internal liabilities & (mld. EUR) & $7.144,3$ & $7.201,1$ & $7.634,1$ \\
\hline External assets & (\%) & $\mathbf{1 1 , 8} \%$ & $\mathbf{1 5 , 1} \%$ & $\mathbf{1 5 , 2 \%}$ \\
\hline Internal asstes & $(\%)$ & $\mathbf{8 7 , 5 \%}$ & $\mathbf{8 5 , 5} \%$ & $\mathbf{8 4 , 8 \%}$ \\
\hline External liabilities & (\%) & $\mathbf{1 1 , 8} \%$ & $\mathbf{1 5 , 1 \%}$ & $\mathbf{1 5 , 2 \%}$ \\
\hline Internal liabilities & $(\%)$ & $\mathbf{8 8 , 2} \%$ & $\mathbf{8 4 , 9 \%}$ & $\mathbf{8 4 , 8 \%}$ \\
\hline
\end{tabular}

Source: Carried out by the author on the basis of data provided by the BCE from the aggregate balance sheet of euro area credit institutions, available at http://sdw.ecb.europa.eu/reports.do?node $=1000005448$ accessed on 16.04 .2020

Table 5 presents the aggregate values of credit portfolios and credit securities held by French MFIs for the years 2017-2019.

Table 5. Aggregate values of credit portfolios and credit securities held by the French banking sector

\begin{tabular}{|c|c|c|c|c|c|}
\hline Portfolio & Sub-portfolio & U.M. & 2017 & 2018 & 2019 \\
\hline Internal assets & & (mld. EUR) & $7.086,5$ & $7.245,8$ & $7.631,4$ \\
\hline \multirow[t]{4}{*}{ Loans } & & (mld. EUR) & 4.893 & 5.364 & 5.658 \\
\hline & Sovereign & (mld. EUR) & 209,7 & 213,7 & 213,8 \\
\hline & $\begin{array}{l}\text { Corporate / } \\
\text { Private }\end{array}$ & (mld. EUR) & $2.428,3$ & 2.703 & 2.825 \\
\hline & MFIs & (mld. EUR) & 2.255 & 2.447 & 2.619 \\
\hline \multirow[t]{4}{*}{ Securities } & & (mld. EUR) & 544,7 & 555 & 599 \\
\hline & Sovereign & (mld. EUR) & 184,8 & 163,4 & 177,9 \\
\hline & $\begin{array}{l}\text { Corporate / } \\
\text { Private }\end{array}$ & (mld. EUR) & 237,4 & 261,7 & 256 \\
\hline & MFIs & (mld. EUR) & 122,5 & 130 & 165,1 \\
\hline
\end{tabular}

Source: Carried out by the author on the basis of data provided by the BCE from the aggregate balance sheet of euro area credit institutions, available at http://sdw.ecb.europa.eu/reports.do? node $=1000005448$ accessed on 16.04 .2020

As can be seen, most domestic assets are included in the loan portfolio, addressed to the corporate and retail (private) segment, with a value of EUR 2.8 trillion in 2019. The second-largest sub-portfolio is that of loans to MFIs. With a value of EUR 2.6 trillion in 2019 and the securities are relatively small, of EUR 599 billion in 2019. Therefore, Table 6 shows the percentage composition of the analyzed portfolios.

Table 6. Percentage composition of portfolios and sub-portfolios of French MFIs for the years 2017-

\begin{tabular}{|c|c|c|c|c|c|}
\hline \multicolumn{6}{|c|}{2019} \\
\hline Portfolio & Sub-portfolio & U.M. & 2017 & 2018 & 2019 \\
\hline \multirow[t]{4}{*}{ Loans } & & $\begin{array}{c}\text { (\% of internal } \\
\text { assets) }\end{array}$ & $69,05 \%$ & $74,03 \%$ & $74,14 \%$ \\
\hline & Sovereign & $(\%)$ & $4,29 \%$ & $3,98 \%$ & $3,78 \%$ \\
\hline & $\begin{array}{l}\text { Corporate / } \\
\text { Private }\end{array}$ & $(\%)$ & $49,63 \%$ & $50,39 \%$ & $49,93 \%$ \\
\hline & MFIs & $(\%)$ & $46,09 \%$ & $45,62 \%$ & $46,29 \%$ \\
\hline \multirow[t]{4}{*}{ Securities } & & $\begin{array}{c}\text { (\% of internal } \\
\text { assets) }\end{array}$ & $7,69 \%$ & $7,66 \%$ & $7,85 \%$ \\
\hline & Sovereign & $(\%)$ & $33,93 \%$ & $29,44 \%$ & $29,70 \%$ \\
\hline & $\begin{array}{l}\text { Corporate / } \\
\text { Private }\end{array}$ & $(\%)$ & $43,58 \%$ & $47,15 \%$ & $42,74 \%$ \\
\hline & MFIs & $(\%)$ & $22,49 \%$ & $23,42 \%$ & $27,56 \%$ \\
\hline
\end{tabular}

Source: Carried out by the author on the basis of data provided by the BCE from the aggregate balance sheet of euro area credit institutions, available at http://sdw.ecb.europa.eu/reports.do?node $=1000005448$, accessed on 16.04 .2020

Analyzing the loan portfolio volume from a dynamic perspective, observing that its contribution to domestic assets from 2017 to 2019 increased by 5\%. The structure of the lending portfolio has not changed significantly, among which in 2019, the French banks granted practically half of the loans to corporate and individuals segments, which constitute $46.29 \%$ to other MFIs as interbank loans. They also credited the 
French state (state institutions) with approximately $3.78 \%$ of its portfolio. Regarding the domestic portfolio of securities, a slightly different situation is highlighted. It still dominates the corporate and private segments with a share of $42.74 \%$ of the total deposits held, the state returning $29.7 \%$ and MFIs- $27.56 \%$. It is necessary to note that the percentage value of the sub-portfolio of sovereign investment securities decreased from $33.9 \%$ to $29.7 \%$ and the corporate/private one from $47.15 \%$ to $42.74 \%$. The difference is due to the increase of the loan sub-portfolio by $4 \%$ for MFIs, from $22.5 \%$ to $27.5 \%$.

Figure 2 shows the macro-statistical structure of the portfolio of income-generating banking investments (assets) for the MFI sector in France.

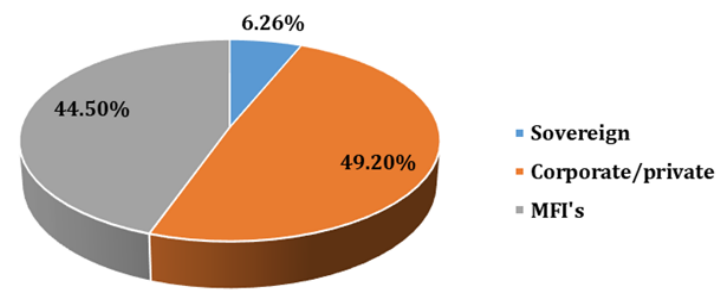

\section{Figure 2. Percentage structure of the internal investment portfolio of the French banking sector for 2019}

Source: Made by the author based on the data in Table 6. Percentage composition of portfolios and sub-portfolios of MFIs in France for the years 2017-2019

As far as we can see, the "Corporate / private" portfolios hold the largest positions with EUR 3,081 billion (49.24\%) and MFIs with EUR 2,784.1 billion (44.50\%), followed by the parts on the category" Sovereign "of EUR 391.7 billion (6.26\%). We note that French banks hold only about 50\% of their domestic portfolio of consumer and business credit investments, and 44\% are granted to other MFIs both in French jurisdiction and in euro area Member States.

\section{Conclusions}

The aggregate level of banking risks regarding financial stability in Romania and France is increasing, and the prospects for the coming years indicate this trend's maintenance. The evaluation of the current financial-banking system does not signal the existence of severe risks. Still, it does identify three high systemic risks: the tension of internal macroeconomic balances, reducing investor confidence in emerging economies, the risk regarding the uncertain legislative framework. As a result of the study, it can be seen that maintaining a stable economic and financial climate with growth trends, encourages the banking system to increase the proportions of lending portfolios. For this reason, in the last 5 years, there has been efficiency of banking operations internally and externally through the good management of minimum required reserves, the inflation rate, and the share of non-performing loans.

\section{References}

1. Buitter, W., Lago, R., Revue d'Économie Financiere, 2001.

2. Downes, J., Goodman, J.E., Dictionary of Finance and Investement Terms, Barron's Publishing House, New York, 2014

3. Dumitriu, M., Zaharia, V., Efficiency, risk and stability, Pro Universitaria Publishing House, Bucharest, 2014.

4. Iosof, S., Gavri, T., Risk management, Editura Universitară, Bucharest, 2013.

5. Lăzărescu, S., Moinescu, B., Pocan, I., Turcanu, M., Risk management and measurement of banking performance, ASE Publishing House, Bucharest, 2004.

6. Lamarque, É., Maymo, V., Économie et gestion de la banque, Dunod, Paris, 2015.

7. Jacques de Larosiere, Financial Transition in Europe and Central Asia, Washington, D.C., 2001.

8. Sylvie des Coussergues, Gestion de la banque: du diagnostic à la stratégie, 5 Edition, Dunod, 2007.

9. The World Bank, Transition - The First Ten Years, Washington, DC, 2002.

10. Regulation no. 19 of 14 dec. 2006 on credit risk mitigation techniques used by credit institutions and investment firms, published in OG, Part 11034 bis 127 dec. 2006.

11. Regulation No. 11 of June 30, 2009, amending Regulation No. 3/2007 on limiting credit risk to loans to individuals, published in the Official Gazette, Part 1 of July 2, 2009.

12. Regulation no. 5/2018 for the amendment and completion of the Regulation of the National Bank of Romania no. 5/2013 on prudential requirements for credit institutions.

13. Norm no. 4/2018, regarding the management of the operational risks generated by the information systems used by the entities authorized/approved/registered, regulated and/or supervised by the Financial Supervisory Authority, published in the Official Gazette, Part I no. 233 of March 16, 2018.

14. Regulation no. 111 of 24 May 2018 on the treatment of credit risk for banks according to the standardized approach, published in the Official Gazette of the Republic of Moldova, no. 183-194, art. 901 of 08.06.2018.

15. https://www.bnr.ro.

16. https://www.banque-france.fr.

17. https://www.bvb.ro.

18. https://www.ecb.europa.eu.

19. https://bnr.ro/Baza-de-date-interactiva-604.

20. http://sdw.ecb.europa.eu/browse.do?node. http://sdw.ecb.europa.eu/reports.do?node 